\title{
Small worlds and short stories: play, pleasure and imagination deployed as a salve to isolated learning
}

\section{Paul O'Kane}

University of the Arts London

Keywords: short stories; small worlds; Walter Benjamin; Covid-19.

\section{The challenge}

The news came at the start of Easter recess. Teaching and learning in our Fine Art department was quickly shifting online in time for the pending summer term. First encounters with Zoom, Collaborate and Teams were inauspicious. All looked dingy and everyone divided. This was a reflection of our unprecedentedly fearful and disorienting containment, rather than a fair representation of online teaching in general. It was this fear and this physical and psychological containment, brought about by the pandemic, that I perceived as the problem I needed to address. As we exposed previously unseen contents of our home offices, everyone seemed faintly amused, albeit masking an underlying existential threat.

Meeting students online involved a similar mix of novelty and nerves but also amplified awareness of pastoral duties. The staff wanted to help alleviate and reassure students, many of whom were now studying in the family home they had recently left to become a Fine Art student in London.

\section{The response}

At first, I fared badly; listening to pandemic news, or glimpsing news flashes on the edge of my screen made me feel depressive and panicky. I boycotted news. This helped, but I found a more effective antidote in a collection of short stories by Haruki Murakami (2006). I read these hunched against a closed window, maximising daylight falling on pages while 
getting as close as I dared to the fearsome outside world. I had left Murakami's collection unread for several years, but now, my theory that every book has its day was proven correct. His breezy descriptions of comfortable lifestyles laced with a curious sense of anomaly brightened my vision sufficiently for me to regain psychological equilibrium. I had suffered some poor mental health as a mature undergraduate and developed strategies to deal with it. Now I thought of colleagues and students who might be suffering in similar ways, and as I began to feel more hopeful, it struck me that even advocating a simple escape into short story reading could help others find a way back to working confidently and enjoyably.

I have long been a fan of short stories, working through collections, comparing styles, techniques, nationalities and eras, as well as publishing some of my own. I had also provided a seminar titled $A$ world of stories for international, culturally diverse groups of Fine Art undergraduates. This pivoted around Walter Benjamin's essay The Storyteller (1968) and also implicated the use of close and contextual readings of short stories selected from Penguin's Parallel Texts series printed in parallel translations (Coward, 1999; Balcom, 2013). It was not a great leap then to devise a new seminar based on short stories and aimed at helping students experiencing newly brief and fragmented learning, and whose imaginations and perspectives might be cramped and curtailed by the pandemic.

A new seminar, Small worlds and short stories, was born. The first part of the title referred to shrunken surroundings and emerged from the idea that an artist or art student does not necessarily need a lot of space, time or money to make interesting and valuable work. Alberto Giacometti supposedly returned to Paris from Switzerland following World War Two with recent figurative works in a matchbox, while Marcel Duchamp made mini versions of major works available in a 'boîte-en-valise' like the sample case of a travelling salesman. Around such precedents and resources, I wrapped further historical and contemporary art examples, plus some theorisation, for example, using Susan Stewart's book On Longing (1984), in which the miniature receives intimate intellectual attention. A catalogue for an exhibition titled Small World at San Diego Museum of Modern Art in 2000 (Kamps and Rugoff, 2000) showed how contemporary art can be a minute proposition for a larger project, or simply revel in the reverie of small worlds - as we all do as children. Another helpful text was Bernd Stiegler's Traveling in place: a history of armchair travel 
(2013), a book that collects, edits and comments upon a rich archive of mostly $19^{\text {th }}$ century literature created by witty and parodic writers describing adventures that take place within the home - often in one room. Furthermore, resilient historical and literary figures, including Defoe's Robinson Crusoe (1994), Swift's Gulliver (1994), Anne Frank, and Nelson Mandela came into play. The fictional characters provided examples of the ways in which literature can imaginatively explore possibilities and impossibilities of scale and of human invention given limited resources. Meanwhile, the real-life figures provided models of belief and perseverance in inauspicious circumstances.

Given these models, and the creative licence to make the most of the seminar and turn our collective catastrophe into an opportunity, students responded well, using a variety of media, from high tech solutions to spoken and written word, animations to dioramas. They also revealed their personal enthusiasm for literature and made new connections between reading that they did 'for themselves' and reading they were required to develop in their studies.

\section{Reflections}

I have provided this seminar, on several occasions now, to different groups and colleges, for BA Fine Art and MA Fine Art students. It always seems to liberate and relax, to show how beautiful the small and how voluminous the short can be, while revealing that even when confined, fine artists (providing models for all) can turn restrictions to advantage. In terms of students' learning, this is a good model of how enjoyment, play and pleasure can be gateways into serious work and learning (James and Nerantzi, 2019), and how an individual's 'small world' of study can and should always be taken seriously as the core of something upon which a lifetime of learning will be built. I am not a scientific pedagogical theorist, but an artist deeply involved in the textures and senses of teaching; however, I would recommend, to interested others, Roger Caillois' Man, play and games (Caillois, 2001) and a close re-reading of Benjamin's The Storyteller essay (1968). These might deepen and extend an understanding or evaluation of my strategies here.

I feel pleased that I was able to turn an oppressive and intimidating experience into a positive interpretation of our newly compressed environment. This created a space of possibility leading to some fundamental, yet recently overlooked aspects of contemporary 
art as rooted in imagination, scale and the pleasures of play. The literature discussed helped show students (and me) that we often need to adjust our presumptions and adapt to our surroundings in order to maintain optimism and carry on sowing seeds of possibility - within ourselves and for others - even (and perhaps especially) in the most isolated and dispirited times and places.

\section{References}

Balcom, J. (2013) Short stories in Chinese. New York: Penguin.

Benjamin, W. (1968) Illuminations. New York: Schocken.

Caillois, R. (2001) Man, play and games. Urbana III: University of Illinois Press.

Coward, R. (1999) Short stories in French. New York: Penguin.

Defoe, D. (1994) Robinson Crusoe. London: Penguin.

James, A., and Nerantzi, C. (eds.) (2019) The power of play in higher education: creativity in tertiary learning. Cham, Switzerland: Springer.

Kamps, T. and Rugoff, R. (2000) Small worlds: dioramas in contemporary art. San Diego: San Diego Museum of Modern Art.

Murakami, H. (2006) Blind willow sleeping woman. London: Harvill Secker.

Stewart, S. (1984) On longing: narratives of the miniature, the gigantic, the souvenir, the collection. Baltimore: John Hopkins University Press

Stiegler, B. (2013) Traveling in place: a history of armchair travel. Chicago: University of Chicago Press.

Swift, J. (1994) Gulliver's Travels. London: Penguin 


\section{Author details}

Paul O'Kane is an artist and writer, lecturing on art and culture at Central Saint Martins College. Paul is a founding member of eeodo artists' publishers and a long-standing member of AICA (International Association of Art Critics). He has published a series of artists' books, and numerous articles, essays, and reviews for leading journals and magazines, including Third Text and Art Monthly. Paul's research, writing, and lecturing is rooted in Fine Art but always informed by a broader cultural field and a historical model. Paul is currently preparing a book on history in contemporary art for Routledge. 